\title{
An Old Lineage of Cyphophthalmi (Opiliones) Discovered on Mindanao Highlights the Need for Biogeographical Research in the Philippines
}

\section{Citation}

Clouse, Ronald M., David M. General, Arvin C. Diesmos, and Gonzalo Giribet. 2011. “An Old Lineage of Cyphophthalmi (Opiliones) Discovered on Mindanao Highlights the Need for Biogeographical Research in the Philippines." Journal of Arachnology 39 (1) (April): 147-153. doi:10.1636/ha10-108.1.

\section{Published Version}

doi:10.1636/ha10-108.1

\section{Permanent link}

http://nrs.harvard.edu/urn-3:HUL.InstRepos:34609596

\section{Terms of Use}

This article was downloaded from Harvard University's DASH repository, and is made available under the terms and conditions applicable to Other Posted Material, as set forth at http:// nrs.harvard.edu/urn-3:HUL.InstRepos:dash.current.terms-of-use\#LAA

\section{Share Your Story}

The Harvard community has made this article openly available.

Please share how this access benefits you. Submit a story.

Accessibility 


\title{
An old lineage of Cyphophthalmi (Opiliones) discovered on Mindanao highlights the need for biogeographical research in the Philippines
}

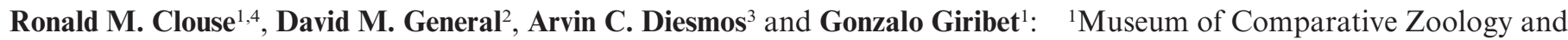 \\ Department of Organismic and Evolutionary Biology, Harvard University, 26 Oxford Street, Cambridge, \\ Massachusetts 02138 USA. E-mail: ronaldmclouse@gmail.com; ${ }^{2}$ School of Forest Resources, University of Arkansas - \\ Monticello, 110 University Court, Monticello, Arkansas 71656 USA; ${ }^{3}$ Herpetology Section, Zoology Division, National \\ Museum of the Philippines, Padre Burgos Avenue, Ermita 1000, Manila, Philippines
}

\begin{abstract}
The arachnid order Opiliones, and the suborder Cyphophthalmi in particular, have recently been used to test biogeographical patterns in Southeast Asia due to their ancient age and extremely low vagility. Here we report the first Cyphophthalmi - two juveniles - known from Mindanao in the southern Philippine Archipelago, and we place them in a molecular phylogeny to test biogeographical hypotheses for their colonization of that island. Five molecular markers were sequenced from one specimen, three from the other, and these sequences were added to a previously completed phylogenetic analysis. The specimens were recovered as members of a clade found almost exclusively on Borneo. Their deep placement within this clade suggests a very old origin and colonization that perhaps involved the mysterious landmass now underlying Mindanao's Zamboanga Peninsula. This species prompts new questions about the abilities of Southeast Asian Cyphophthalmi (Stylocellidae) to disperse and colonize, and it emphasizes how much remains to be understood about the geological history of the Philippines.
\end{abstract}

Keywords: Southeast Asia, Borneo, Zamboanga, harvestmen, stylocellidae, biogeography

Cyphophthalmi is a suborder of Opiliones, and most of its members are exceptionally poor dispersers. Species have highly constrained ranges (Giribet 2000), or, if widespread, demonstrate little gene flow between populations (e.g., Boyer et al. 2007a for Aoraki denticulata [Forster 1948]; R. Clouse unpublished data for Metasiro americanus [Davis 1933]). The Southeast Asian Cyphophthalmi, all in the family Stylocellidae, have been shown to have a few cases of trans-oceanic dispersal (Clouse \& Giribet 2007), but their phylogeny matches hypothesized geologic events close enough to suggest that their present distribution is mostly due to vicariance (Clouse \& Giribet 2010), as is characteristic for the suborder as a whole (Boyer et al. 2007b).

The biogeography of Southeast Asia is commonly noted for the region's distinct biotic boundaries, and before the acceptance of continental drift, these breaks were the first clues that landmass configurations had changed dramatically over time (Wallace 1859; Simpson 1977). Today most of these biotic breaks are seen as collective limits for organisms of similar origins, dispersal capabilities, and ecological requirements (Mayr 1944), but some have also been shown to have dubious meaning altogether. In the latter category is Huxley's line, which separates Borneo and Palawan (Fig. 1) from the remainder of the Philippines; it was based on the range limits for certain avian species, particularly megapodes and pheasants (Huxley 1868).

Huxley's line does mostly separate continental landmasses (Borneo and Palawan) from those of oceanic and volcanic origins, although this appears to be incomplete, coincidental, and rather meaningless vis-à-vis biogeographic questions. Palawan is hypothesized to be continental crust moving south

${ }^{4}$ Current address: Division of Invertebrate Zoology, American Museum of Natural History, Central Park West at $79^{\text {th }}$ St., New York, New York 10024 USA from the Chinese coastline with the opening of the South China Sea, but along with it likely came Mindoro and perhaps even parts of Zamboanga (Fig. 2) (Yumul et al. 2004), which Huxley grouped with the volcanic Philippine islands. In addition, Palawan's positioning close to (and perhaps connected to) Borneo is a relatively recent phenomenon, happening only in the past 10 million years, in contrast to various volcanic formations that formed earlier off the coast of Borneo and are now part of the Philippine Archipelago (Hall 2002; Yumul et al. 2009). Cases of lineages of organisms that cross Huxley's line have made obsolete the notion that Philippine biogeography is best understood by a single biotic break between it and Borneo, and Palawan in particular has been shown to play different roles for different lineages (Essylstyn et al. 2010; Oliveros \& Moyle 2010; Siler et al. 2010). Crossings of Huxley's line are especially interesting when looking at poor dispersers, like freshwater amphibians. For example, Southeast Asian stream frogs (Rana signata complex) have apparently invaded the Philippines from Borneo via Palawan and Mindoro, as well as possibly through the Sulu Archipelago and Mindanao (Brown \& Guttman 2002), and oriental stream toads (Ansonia) appear to have crossed Huxley's line from Borneo to Mindanao (Matsui et al. 2010).

Cyphophthalmi, perhaps the least vagile animals in the region, have previously appeared to occur only west of Huxley's line, having been described from Palawan Island and Borneo but not from the remainder of the Philippines (Shear 1993; Clouse et al. 2009), but here we report the first Cyphophthalmi (Figs. 3-8) from the island of Mindanao in the southern Philippines, yet another exception to this supposed faunal break. We have previously reported a firsthand account of perhaps seeing Cyphophthalmi from Luzon by P. Schwendinger (Clouse \& Giribet 2007), but further information or a specimen has not been available. Our objective upon finding the Mindanao specimens was to narrow the possible scenarios for their origin by placing them 

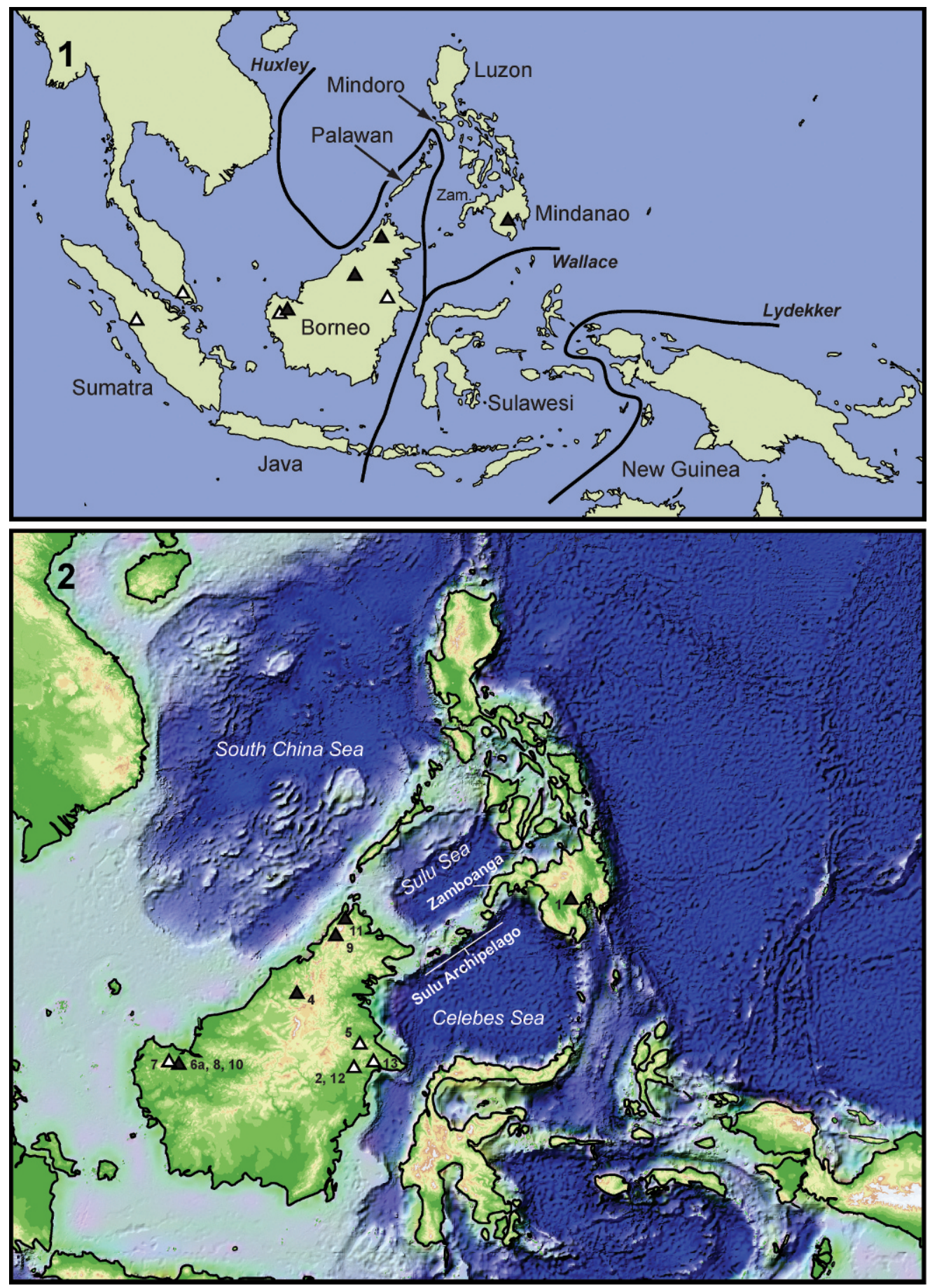

Figures 1, 2.- Southeast Asia, showing Miopsalis localities, with species from clades I and II designated by open triangles and from clade III by filled (black) triangles. 1. Biotic breaks demarcated by Huxley, Wallace and Lydekker; "Zam." = Zamboanga Peninsula on western Mindanao; 2. The topography and bathymetry of the northeastern Malay Archipelago.

in a recently completed, dated phylogeny of the Southeast Asian Cyphophthalmi (all in Stylocellidae) (Clouse \& Giribet 2010). From this phylogeny, we have inferred that stylocellids arrived in Southeast Asia on the Sibumasu terrane, which rifted from Gondwana in the late Paleozoic; the genus Fangensis is an old lineage in the family and still found exclusively on the Sibumasu. From there, the genus Meghalaya extended north as far as northeast India and China's
Yunnan Province, and then, after the appearance of Borneo in the late Mesozoic, the genus Miopsalis expanded into that landmass while it was still connected to the Thai-Malay Peninsula. A fourth and final clade, Leptopsalis, diversified over the whole southern end of the once-unified Sundaland Peninsula (and into eastern Thailand; see Clouse \& Giribet 2010:fig. 1) before it broke apart into today's Indo-Malay Archipelago, carrying stylocellid lineages presently found on 

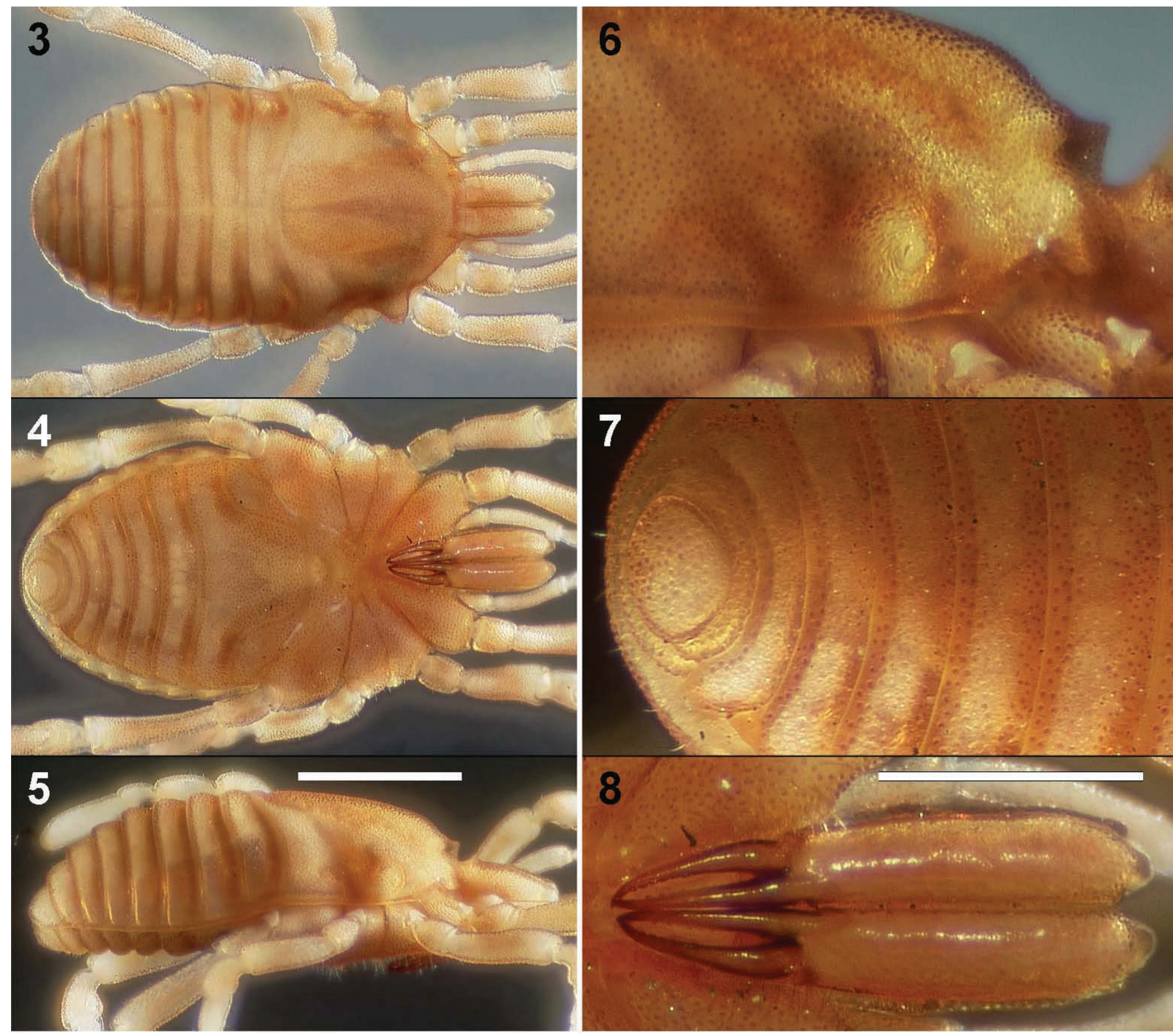

Figures 3-8.-A juvenile cyphophthalmid collected from Mindanao Island, Philippines. 3. Dorsal; 4. Ventral; 5. Lateral; 6. Lateral anterior; 7. Ventral posterior; 8. Chelicers. Scale bars equal $1 \mathrm{~mm}$ (Figs. 3-5); $0.50 \mathrm{~mm}$ (Figs. 6-8).

Java, Sumatra, and Sulawesi. (The remaining genus in the family, Stylocellus, which currently contains the bulk of the named species in the family, has not had its type specimen placed reliably in the four main lineages [Clouse et al. 2009].) Before sequencing the Mindanao species we were unsure if it would fall in Miopsalis, found almost exclusively on Borneo, or in Leptopsalis, which is found throughout the Indo-Malay Archipelago, including Northern Sulawesi directly to the south. Northern Sulawesi Leptopsalis are also related to species on New Guinea (Clouse \& Giribet 2007), indicating a possible proclivity for dispersal in that group.

\section{METHODS}

On December 15-16, 2009, leaf litter that was later found to have two juvenile cyphophthalmids was collected from the following location: Barangay (village) Kimlawis, Municipality of Kiblawan, Davao del Sur Province, in the central region of Mindanao (estimated coordinates: $06.47836^{\circ}-06.48528^{\circ} \mathrm{N}$, $\left.125.08317^{\circ}-125.08689^{\circ} \mathrm{E}\right)$. The litter was collected from two remnant patches of degraded, logged-over, lowland forest at about $500 \mathrm{~m}$ above sea level.

The specimens are presently stored at $-80^{\circ} \mathrm{C}$ in $95 \% \mathrm{EtOH}$ in the Department of Invertebrate Zoology at the Museum of Comparative Zoology (Harvard University) under collection number MCZ DNA104981. We attempted to sequence fragments of $16 \mathrm{~S}$ rRNA ( $\sim 70 \mathrm{bp}), 18 \mathrm{~S}$ rRNA ( $1760 \mathrm{bp})$, $28 \mathrm{~S}$ rRNA $(\sim 2100 \mathrm{bp})$, cytochrome $c$ oxidase subunit I ("COI," 814 bp), histone H3 (327 bp), and histone H4 (160 bp). Only 16S rRNA did not amplify for either specimen, and the smaller specimen did not produce sequence data for COI or histone H3. Completed sequences are deposited in GenBank under accession numbers HQ593865-HQ593872. 


\section{9}

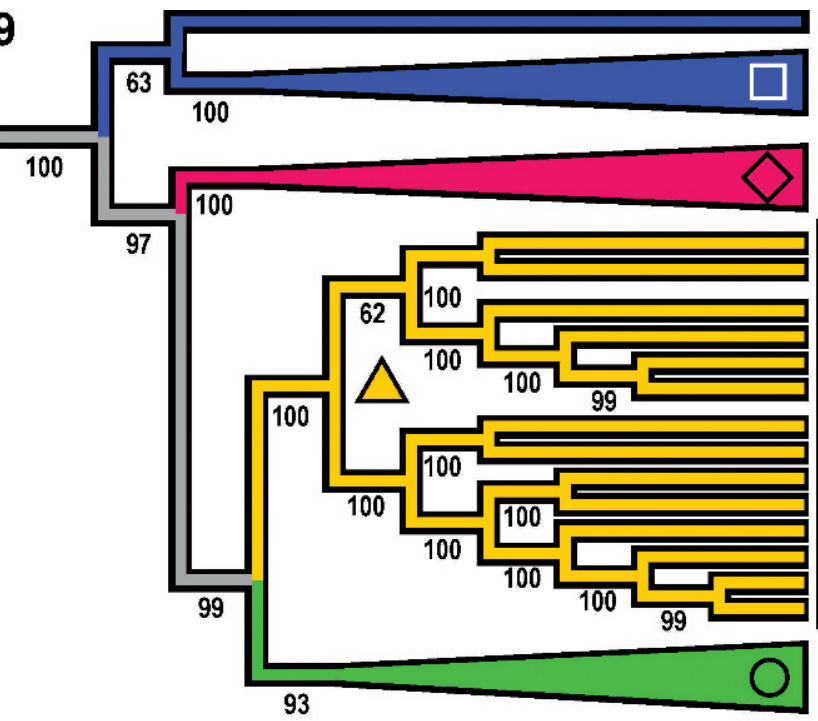

Fangensis insulanus

Fangensis

Meghalaya

Borneo sp. 2 female

Borneo sp. 5 female

Sumatra sp. 13

Borneo sp. 7

Borneo sp. 12

Borneo sp. 13

Mindanao sp. 1 juvenile a

Mindanao sp. 1 juvenile b

Borneo sp. 8

Borneo sp. 10

Borneo sp. 6 a

Borneo sp. 4 female

Borneo sp. 9 female

Borneo sp. 11

Leptopsalis

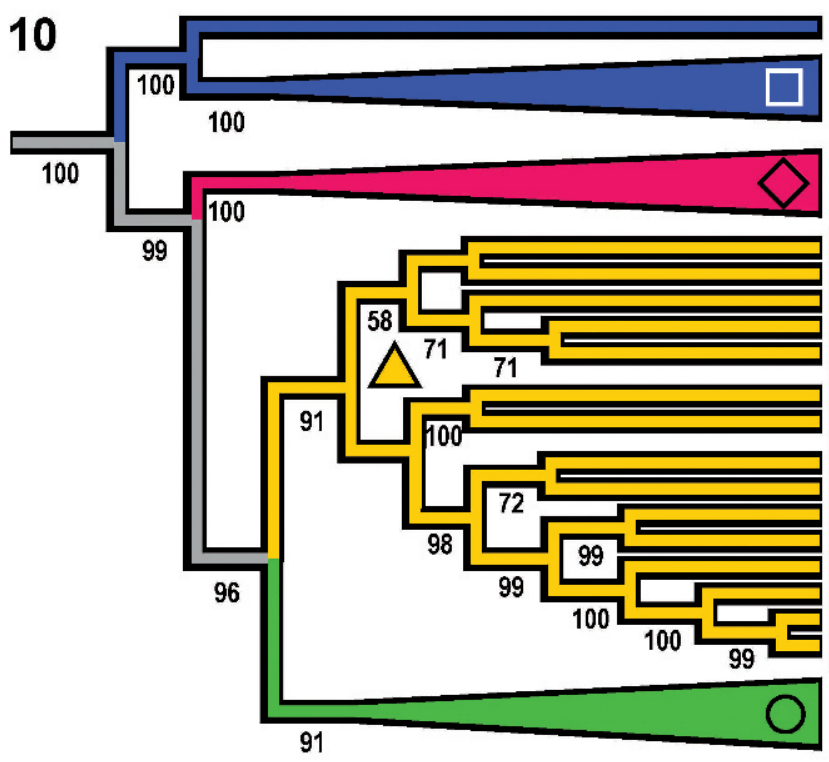

Fangensis insulanus

Fangensis

Meghalaya

Sumatra sp. 13

Sumatra sp. 13
Peninsula sp. 28

Borneo sp. 7

Borneo sp. 12

Borneo sp. 13

Borneo sp. 2 female

Borneo sp. 5 female

Mindanao sp. 1 juvenile a

Mindanao sp. 1 juvenile b

Borneo sp. 8

Borneo sp. 10

Borneo sp. 6a

Borneo sp. 4 female

Borneo sp. 9 female

Borneo sp. 11

Leptopsalis

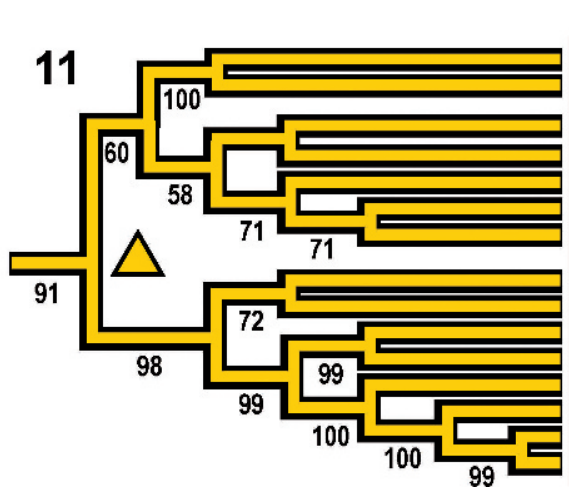

Borneo sp. 2 female

Borneo sp. 5 female

Sumatra sp. 13

Peninsula sp. 28

Borneo sp. 7

Borneo sp. 12

Borneo sp. 13

Mindanao sp. 1 juvenile a

Mindanao sp. 1 juvenile b

Borneo sp. 8

Borneo sp. 10

Borneo sp. 6 a

Borneo sp. 4 female

Borneo sp. 9 female

Borneo sp. 11

Figures 9-11.-Phylogenetic hypotheses for the placement of the juvenile Mindanao cyphophthalmids (sp. 1a and 1b, arrows). Collection symbols (square, diamond, triangle, circle) and species monikers match Clouse and Giribet (2010). The clades Fangensis, Meghalaya, and Leptopsalis have been collapsed, with the exception of $F$. insulanus, which is often recovered as sister to the non-Fangensis stylocellids. Fangensis is found in the northern and central parts of the Thai-Malay Peninsula, Meghalaya in the Thai-Malay Peninsula and Eastern Himlayas, and Leptopsalis in the IndoMalay Archipelago. Support values under each node are jackknife values using original data partitions. 9. The phylogeny does not include the terminal "Peninsula sp. 28 " and is 24,304 weighted steps long. 10. The shortest tree (24,341 weighted steps) including Peninsula sp. 28 (arrow), which caused clade I to become sister to III. 11. With "Peninsula sp. 28", there was higher jackknife support for the original position of clade I as sister to II. 
We used a recently completed comprehensive study of Southeast Asian Cyphophthalmi (Clouse \& Giribet 2010) to place the Mindanao species in a large phylogeny efficiently. This phylogeny was comprised of six non-cyphophthalmid Opiliones, 21 non-stylocellid Cyphophthalmi, and 95 Stylocellidae, representing the Eastern Himalayas, the Thai-Malay Peninsula, Sumatra, Borneo, Sulawesi, Java, and New Guinea. First, we added the Mindanao terminals as basal branches to one of the shortest trees found earlier under each of nine different transformation cost schemes. We then applied traditional branch swapping as well as a genetic algorithm to those nine trees using POY version 4.1.2 (Varón et al. 2009) on 20 parallel nodes under the previous study's optimal cost scheme ("121," where indels and transversions cost two and transitions cost one). This addition of terminals to previously found trees is akin to Mecham et al.'s (2006) "jumpstarting" and Giribet's (2007) "pre-processed searches." After finding the shortest trees containing the Mindanao terminals, we added the critical terminal "Peninsula sp. 28" from Kota Tinggi, Johor, Malaysia, and did another round of searching. "Peninsula sp. 28" is known from a single specimen, has only the 18S rRNA fragment and less than half of the 28S rRNA fragment sequenced, but morphologically it resembles other species in the genus Miopsalis and was recovered there in previous phylogenetic searches.

Nodal support was evaluated with 100 jackknife pseudoreplicates, each starting from trees found earlier under cost schemes 111 (all transformations equal) and 441 (indels cost 16 , transversions cost four, and transitions cost one), and with the Mindanao and "Peninsula sp. 28" terminals added as basal branches. Dynamic homology was used during the jackknife searches, with the data fragmented into the same partitions used during the original tree searches. The jackknife removal percentage, which in the dynamic homology context refers to the percent of data partitions randomly removed to generate each pseudoreplicate, was set at 0.36 (Farris et al. 1996). Clades are here referred to by their tentative genus names pending an ongoing revision of the family (see Clouse 2010).

Dates for the origins of the Mindanao species were approximated from the dates estimated earlier for Stylocellidae (Clouse \& Giribet 2010). That analysis was done by setting the root to $425 \mathrm{Ma}$ and making nodal date estimates in the program r8s 1.71 (Sanderson 2003). The date for the root was based on an early Devonian fossil opilionid (Dunlop et al. 2004) and the hypothesis that Opiliones are sister to Scorpiones, for which mid-Silurian stem-group fossils are known (Giribet et al. 2002; Dunlop et al. 2007).

\section{RESULTS}

Despite juveniles lacking important taxonomic characters, morphology initially suggested that the Mindanao specimens are stylocellids: presence of a solea (concentration of setae) on tarsus of leg I, ornamented tarsi in all legs, coxa of leg II fused to coxae III-IV, C-shaped tracheal spiracles, and sculpturing on the second cheliceral article (Giribet 2002). This was supported by our molecular analysis. Within Stylocellidae, the two Mindanao specimens (likely the same species) placed inside the genus Miopsalis as sister to ones found exclusively on Borneo (Fig. 9, clade III). When "Peninsula sp. 28" was added, that species placed inside clade II as sister to the Sumatran species (Fig. 10). "Peninsula sp. 28"'s inclusion also caused clade I to become sister to clade III, but there was actually $60 \%$ resampling support for the original position of clade I as sister to clade II (Fig. 11). This general arrangement of clades within Miopsalis, as well as the close placement of Sumatran and Peninsular species inside clade II, match results from our earlier analyses (Clouse \& Giribet 2010). Previously we estimated that clades (I + II) and III split $168 \mathrm{Ma}$, that clade III (without the Mindanao species) started diversifying around $100 \mathrm{Ma}$, and clades I and II split at $116 \mathrm{Ma}$. Our bestsupported phylogenies (Figs. 9, 11) suggest that the Mindanao lineage originated between 100 and $168 \mathrm{Ma}$, from the Middle Jurassic to the Early Cretaceous. The shortest tree with "Peninsula sp. 28" supports the earlier end of this estimate, between 100 and $116 \mathrm{Ma}$.

The phylogenetic results closely matched our previous hypotheses constructed before the Mindanao species was discovered (Clouse \& Giribet 2010), with the one exception of Fangensis being recovered as monophyletic (Figs. 9, 10) in the shortest tree found under the optimal parameter set. However, this result was not surprising, often being found under different parameter sets, and well-supported, stable clades among the other 122 terminals were recovered again here.

\section{DISCUSSION}

The Mindanao species could have arrived by transoceanic dispersal, especially since the old age of this lineage improves the chances of encountering rare dispersal events. Stylocellidae may also have both intrinsic and external advantages in surviving open seas and colonizing coastal areas (i.e., participating in taxon cycles according to Wilson 1961). The large sizes of many species (especially on Borneo) and highly sclerotized cuticle may help prevent desiccation, and their well-developed eyes may help them find their way out of suboptimal conditions. Furthermore, the presence of many islands throughout Southeast Asia may minimize their time spent at sea relative to other regions.

Nonetheless, any route that maximizes contact with humid leaf litter under a closed canopy (Cyphophthalmi's exclusive habitat, with a few exceptions of subterranean environments) would be the most likely one used by the Mindanao species from Borneo. Two commonly proposed routes to Mindanao, whether by island hopping or land bridges, are 1) via Palawan, Mindoro, and the volcanic islands of the Philippine Archipelago, and 2) via the Sulu Archipelago. However, the Mindanao species represents a very old lineage, and the conditions for land bridges over these two routes (Palawan's arrival and eustatic extremes) have been recent (Yumal et al. 2009). Old lineages can still have recent dispersal events, but a second problem is that the Mindanao species are most closely related to species in western Borneo $(8,10$, and $6 \mathrm{a})$, not, as one would expect, to the ones in closest proximity (Figs. 1, 2, 9-11).

A third possible route to Mindanao, especially for old lineages, may come from the Zamboanga Peninsula, which appears to have been in closer proximity to Borneo for a longer period of time than the remainder of Mindanao. Hall (2002) reconstructed Zamboanga as having arisen near northeastern Borneo $50 \mathrm{Ma}$ and only moving away to join the remainder of Mindanao in the past $5 \mathrm{Ma}$. Explicit 
reconstructions of land exposure for arc, ophiolitic, and accreted material by Hall $(1998,2001)$ also show Zamboanga and Mindanao as having small areas above sea level around volcanoes as far back as at least $30 \mathrm{Ma}$, although hypotheses of exposure for any landmass in Southeast Asia, especially in the Cenozoic, are accompanied by considerable uncertainty (Voris 2000; Lambeck \& Chappell 2001). In 2002, Hall noted evidence for continental material in Zamboanga but also the newness and variable quality of data on Philippine geology, adding yet more intrigue and uncertainty to its history. Geologic data on Zamboanga has since improved, and some see a strengthening case for it having once been part of Palawan (Yumul et al. 2004). What is clear is that the history of Mindanao is far from settled, and the door is open to ancient colonizations or range expansions into Zamboanga before the remainder of Mindanao formed.

Matsui et al. (2010) dated the split between Bornean and Mindanao stream toads at $39 \mathrm{Ma}$ and between two Mindanao species at $20.2 \mathrm{Ma}$, leading them to argue against their methods in order to avoid the unlikely scenario of two invasions of Minadano over Pleistocene land bridges, which formed more than 18 million years later. Blackburn et al. (2010) also found very old dates for the origin of flat-headed frogs on Palawan and Borneo, prompting them to invoke a "Palawan Ark" rafting scenario. For the Mindanao stylocellids, our phylogenetic and dating estimates would need to be highly erroneous to push their origin from the Mesozoic to the Pleistocene, and so we have explored other options to explain their odd occurrence. Zamboanga appears to offer new possibilities for explaining past crossings of Huxley's line, although much work remains to clarify its role in Southeast Asian biogeography. If species dispersed directly from Borneo to proto-Zamboanga, this should be quite discernible in species distributions and phylogenetic analyses as more Cyphophthalmi are discovered in the region.

\section{ACKNOWLEDGMENTS}

We are grateful to the National Museum of the Philippines, Michael de Guia (Maunsell Philippines, Inc.), and Sagittarius Mines, Inc., for making the specimens available for examination. Scott Walker of the Harvard Map Collection generated the topographic and bathymetric map, and Stephanie Aktipis helped edit figures. The comments of anonymous reviewers improved this manuscript significantly.

\section{LITERATURE CITED}

Blackburn, D.C., D.P. Bickford, A.C. Diesmos, D.T. Iskandar \& R.M. Brown. 2010. An ancient origin for the enigmatic flat-headed frogs (Bombinatoridae: Barbourula) from the islands of Southeast Asia. PLoS One 5:1-10.

Boyer, S.L., J.M. Baker \& G. Giribet. 2007a. Deep genetic divergences in Aoraki denticulata (Arachnida, Opiliones, Cyphophthalmi): a widespread 'mite harvestman' defies DNA taxonomy. Molecular Ecology 16:4999-5016.

Boyer, S.L., R.M. Clouse, L.R. Benavides, P. Sharma, P.J. Schwendinger, I. Karunarathna \& G. Giribet. 2007b. Biogeography of the world: a case study from cyphophthalmid Opiliones, a globally distributed group of arachnids. Journal of Biogeography 34:2070-2085.

Brown, R.M. \& S.I. Guttman. 2002. Phylogenetic systematics of the Rana signata complex of Philippine and Bornean stream frogs: reconsideration of Huxley's modification of Wallace's Line at the
Oriental-Australian faunal zone interface. Biological Journal of the Linnean Society 76:393-461.

Clouse, R.M. 2010. Molecular and morphometric phylogenetics and biogeography of a Southeast Asian arachnid family (Opiliones, Cyphophthalmi, Stylocellidae). Ph.D. thesis, Harvard University, Cambridge, Massachusetts.

Clouse, R.M. \& G. Giribet. 2007. Across Lydekker's Line - first report of mite harvestmen (Opiliones: Cyphophthalmi: Stylocellidae) from New Guinea. Invertebrate Systematics 21:207-227.

Clouse, R., B.L. de Bivort \& G. Giribet. 2009. A phylogenetic analysis for the Southeast Asian mite harvestman family Stylocellidae (Opiliones : Cyphophthalmi) - a combined analysis using morphometric and molecular data. Invertebrate Systematics 23:515-529.

Clouse, R.M. \& G. Giribet. 2010. When Thailand was an island-the phylogeny and biogeography of mite harvestmen (Opiliones, Cyphophthalmi, Stylocellidae) in Southeast Asia. Journal of Biogeography 37:1114-1130.

Dunlop, J.A. 2007. Paleontology. Pp. 247-265. In Harvestmen: The Biology of Opiliones. (R. Pinto-da-Rocha, G. Machado \& G. Giribet, eds.). Harvard University Press, Cambridge, Massachusetts.

Dunlop, J.A., L.I. Anderson, H. Kerp \& H. Hass. 2004. A harvestman (Arachnida: Opiliones) from the Early Devonian Rhynie cherts, Aberdeenshire, Scotland. Transactions of the Royal Society of Edinburgh - Earth Sciences 94:341-354.

Esselstyn, J.A., C.H. Oliveros, R.G. Moyle, A.T. Peterson, J.A. McGuire \& R.M. Brown. 2010. Integrating phylogenetic and taxonomic evidence illuminates complex biogeographic patterns along Huxley's modification of Wallace's Line. Journal of Biogeography 37:2054-2066.

Farris, J.S., V.A. Albert, M. Källersjö, D. Lipscomb \& A.G. Kluge. 1996. Parsimony jackknifing outperforms neighbor-joining. Cladistics 12:99-124.

Giribet, G. 2000. Catalogue of the Cyphophthalmi of the world (Arachnida, Opiliones). Revista Ibérica de Aracnología 2:49-76.

Giribet, G. 2002. Stylocellus ramblae, a new Stylocellid (Opiliones, Cyphophthalmi) from Singapore, with a discussion of the family Stylocellidae. Journal of Arachnology 30:1-9.

Giribet, G., G.D. Edgecombe, W.C. Wheeler \& C. Babbitt. 2002. Phylogeny and systematic position of Opiliones: a combined analysis of chelicerate relationships using morphological and molecular data. Cladistics 18:5-70.

Giribet, G. 2007. Efficient tree searches with available algorithms. Evolutionary Bioinformatics 3:341-356.

Hall, R. 1998. The plate tectonics of Cenozoic SE Asia and the distribution of land and sea. Pp. 99-132. In Biogeography and Geological Evolution of SE Asia. (R. Hall \& J.D. Holloway, eds.). Backhuys, Leiden, The Netherlands.

Hall, R. 2001. Cenozoic reconstructions of SE Asia and the SW Pacific: changing patterns of land and sea. Pp. 35-56. In Faunal and Floral Migrations and Evolution in SE Asia-Australasia. (I. Metcalfe, J.M.B. Smith, M. Morwood \& I. Davidson, eds.). A.A. Balkema, Lisse, The Netherlands.

Hall, R. 2002. Cenozoic geological and plate tectonic evolution of SE Asia and the SW Pacific: computer-based reconstructions, model and animations. Journal of Asian Earth Sciences 20:353-431.

Huxley, T.H. 1868. On the classification and distribution of the Alectoromorphae and Heteromorphae. Proceedings of the Zoological Society of London, 294-319.

Lambeck, K. \& J. Chappell. 2001. Sea level change through the last glacial cycle. Science 292:679-686.

Matsui, M., A. Tominaga, W.Z. Liu, W. Khonsue, L.L. Grismer, A.C. Diesmos, I. Das, A. Sudin, P. Yambun, H.I.S. Yong, J. Sukumaran \& R.M. Brown. 2010. Phylogenetic relationships of Ansonia from Southeast Asia inferred from mitochondrial DNA 
sequences: systematic and biogeographic implications (Anura: Bufonidae). Molecular Phylogenetics and Evolution 54:561-570.

Mayr, E. 1944. Wallace's Line in the light of recent zoogeographic studies. Quarterly Review of Biology 19:1-44.

Mecham, J., M. Clement, Q. Snell, T. Freestone, K. Seppi \& K. Crandall. 2006. Jumpstarting phylogenetic analysis. International Journal of Bioinformatics Research and Application 2:19-35.

Oliveros, C.H. \& R.G. Moyle. 2010. Origin and diversification of Philippine bulbuls. Molecular Phylogenetics and Evolution 54:822-832.

Sanderson, M.J. 2003. r8s: inferring absolute rates of molecular evolution and divergence times in the absence of a molecular clock. Bioinformatics 19:301-302.

Shear, W.A. 1993. New species in the opilionid genus Stylocellus from Malaysia, Indonesia and the Philippines (Opiliones, Cyphophthalmi, Stylocellidae). Bulletin of the British Arachnological Society 9:174-188.

Siler, C.D., J.R. Oaks, J.A. Esselstyn, A.C. Diesmos \& R.M. Brown. 2010. Phylogeny and biogeography of Philippine bent-toed geckos (Gekkonidae: Cyrtodactylus) contradict a prevailing model of Pleistocene diversification. Molecular Phylogenetics and Evolution 55:699-710.

Simpson, G.G. 1977. Too many lines; the limits of the Oriental and Australian zoogeographic regions. Proceedings of the American Philosophical Society 121:107-120.
Varón, A., L. Sy Vinh \& W.C. Wheeler. 2009. POY version 4: phylogenetic analysis using dynamic homologies. Cladistics 26:72-85.

Voris, H.K. 2000. Maps of Pleistocene sea levels in Southeast Asia: shorelines, river systems and time durations. Journal of Biogeography $27: 1153-1167$.

Wallace, A.R. 1859. Letter from Mr. Wallace concerning the geographical distribution of birds. Ibis 1:449-454.

Wegener, A. 1912. Die Entstehung der Kontinente. Geologische Rundschau 3:276-292.

Wilson, E.O. 1961. The nature of the taxon cycle in the Melanesian ant fauna. American Naturalist 95:169-193.

Yumul, G.P. Jr., C.B. Dimalanta, R.A. Tamayo, Jr., R.C. Maury, H. Bellon, M. Polve, V.B. Maglambayan, C.L. Querubin \& J. Cotten. 2004. Philippines: an enigmatic South China continental fragment? Pp. 289-312. In Geology of the Zamboanga Peninsula, Mindanao, Philippines: an enigmatic South China continental fragment? Aspects of the Tectonic Evolution of China. (J. Malpas, C.J.N. Fletcher, J.C. Aitchison \& J.R. Ali, eds.). Geological Society of London Special Publication. Volume 226.

Yumul, G.P., C.B. Dimalanta, E.J. Marquez \& K.L. Queano. 2009. Onland signatures of the Palawan microcontinental block and Philippine mobile belt collision and crustal growth process: a review. Journal of Asian Earth Sciences 34:610-623.

Manuscript received 9 November 2010, revised 1 March 2011. 